\title{
A Few Notes on the Contemporary Common Reader
}

In my paper I attempt to establish a starting point for a critique of the idea of the "common reader" as it is used in contemporary literary criticism. The "common reader" was famously developed as a separate theoretical construct by Samuel Johnson and popularized by Virginia Woolf. Today, this idea is being further popularized and simplified though largely unconsciously - by both literary critics and mainstream journalists as a means of erasing the possibility of a genuine political conflict/debate. The "common reader" is perceived as a reader without a class, identity or any social background. I argue that in order to undertake a credible and deliberate critique of the "common reader" one has to go beyond the Johnson-Woolf paradigm and into the territory of the so-called everyday life studies a Situationist-influenced tradition combining culture studies, literary theory and political philosophy.

Keywords: common reader, Situationist International, Spectacle, everyday life, literary criticism 


\section{How to Approach the Common Reader?}

To say that in contemporary humanities there are few concepts as widespread, as intuitive and as imprecise as the idea of "common reader" would be a large understatement. It is one of the things that I've learnt while working on this essay: basically everyone, at least in the academy, has something to say about the very essence or essential features of the "common reader" - and it's probably perfectly normal to have an individual image of what the "common reader" does and what he/she looks like. One could perhaps even argue that creating this image is among the necessary conditions of studying any of the humanities or social sciences, but this is not the point I'm interested in making here.

What I would like to show is that an intuitive and sentimental approach towards the idea of "common reader" - an approach that's gaining popularity among literary critics and scholars alike - may help delegitimise (under the pretense of a more egalitarian and democratic culture) various types of criticism, critical thought and experimental literature/art.

The common reader usually appears as a part of a larger, two-part mechanism, a practical opposition of the "common" versus the "academic", "professional" or "intellectual". From the academic or scholarly point of view, the common reader is a synonym for an outsider, a subaltern, or the Other. This is the form in which he appears in the canonic collection of essays by Virginia Woolf - Woolf, who begins with a quote from Samuel Johnson, defines the "common reader" in an almost purely negative way: as "uncorrupted by literary prejudices", "worse educated", unbiased by the will to "impart knowledge or correct the opinions of others", "hasty, inaccurate, and superficial", "without caring where he finds it [a poem] or of what nature it may be so long as it serves his purpose and rounds his structure" (Woolf 2013). This description would mean nothing, were it not for a contrasting stereotypical image of a "professional reader", subtly evoked by Woolf between the verses. What remains as a positive feature of the "common reader" is the "common sense", a concept in itself almost as undefined as the common reader, and yet almost as intuitive.

Obviously, Johnson's understanding of the term "common reader" and its Woolfian reinterpretation started a long tradition, both in literary studies and in the more non-academical field of critical essay; books like Anne Fadiman's Ex Libris: Confessions of a Common Reader (Fadiman 2000) being an example of the latter. The main problem with Johnson's idea is that although the "common reader" is here seen 
as a kind of a primary or natural condition (untainted by the "literary prejudices", "refinements of subtlety" and "dogmatism of learning"), it is still only possible to define or picture him or her in opposition to his well-educated, refined, subtle and dogmatic counterpart. In other words, although there is a strong implicit suggestion that the "common reader" is a fully autonomous figure, he can be described only as non-academic, non-professional, non-intellectual, etc.

A perfect example of this illusionary autonomy of the "common reader" is Terry Eagleton's review of Fredric Jameson's Marxism and Form (Eagleton 2009). Here, one of the best-known contemporary Marxist literary critics accuses another one of saying "very little about what the common reader, even the common leftist reader, will surely carry away from The Magic Mountain and Doctor Faustus". At the same time Eagleton makes no pretense of knowing what the "common reader" or its "leftist" equivalent actually stands for. From a certain point of view the observation that Jameson is not interested in the reading habits of a "common reader" may be considered a tautology - after all, the "common readers" are precisely those readers who do not read Jameson. But this is beside the point. It is obviously not without merit to argue that Jameson often writes for a purely academic audience. What's important is that Eagleton may elaborate on how Jameson remains blind to the problems of the common reader without being any closer than Jameson to understanding what the words "common reader" actually mean. Once again, a critic's intuition is enough; to speak on behalf of the "common reader" one does not have to define who constitutes the population of "common readers".

Even Richard Altick's well-known The English Common Reader: A Social History of the Mass-Reading Public, 1800-1900 from 1957, although groundbreaking in its study of reading habits in an industrial society, basically equated - operating on the same premise as Jameson and Eagleton - the "common reader" with the "reading masses" (Altick 1957).

Obviously, it is difficult to summarise various contemporary uses of the "common reader" concept - and it is almost impossible to create any kind of "comprehensive comparison". It is partly due to the sheer number of times the phrase "common reader" appears in various essays, articles, columns, blogs, etc. A quick Google search returns an overwhelming number of 600000 references; even more, should one include the phrases "ordinary reader" and "general reader" as well. ${ }^{1}$ And if we

1 I have assumed that the closest Polish equivalent to three of the key English terms - the "common reader", the "ordinary reader" and the "general reader" - 
venture beyond the Woolfian tradition - into the field of popculture studies and semiotic studies, for example - it becomes clear that one has to radically narrow down one's search. Everyone has something to say about the common reader - but the difficult part is to filter out all those voices which refer to a purely intuitive understanding of this figure.

Among those very few critics and theorists who tried to grasp and deconstruct the idea of common reader from within the tradition that originally forged the term was Frank Kermode. In his essay from 1983 he argues that in Johnson's original vision the "common reader" held a very specific class position, somewhere between the "masses" and the "scholars", with his "commonality" being not a sign of his status as a "commoner", but of the individual freedom and right to leisure he enjoyed as a member of the bourgeois (Kermode 1983).

And even though Kermode seems to fall a little short of criticizing the idea of "common reader" in specifically political terms (he never asks, for instance, about the political agenda of the common reader's advocates), he still succeeds in at least two things. First, he suggests that the "common reader" must always be seen through a fundamentally critical perspective - that is, with an assumption that there is a hidden, implicit, specific meaning behind the seemingly intuitive concept of "commonality". Second, he shows how the idea of a "common reader" is not merely an expression of a universal intuition, but an instrument of power within the literary field. In fact, in the last few paragraphs of the essay, Kermode explicitly states that in order to have a common reader the literary criticism must invent or create a common reader - and to do that, one may presume, the critics need to use some kind of "power" or "authority" inherent within their profession (even if, as Kermode explicitly says, there is no "central authority" in criticism, no single authority with the power "to make and uphold canons", which is obviously in itself quite a controversial statement). Also, when talking about the original quotation from Johnson, Kermode reminds us that "in rejoicing to concur with the Common Reader, he [Johnson] was of course making it evident that he himself was a different animal altogether" (ibid., 2). Indeed, for many critics it may seem unfortunate and uncomfortable that even the greatest advocates of the Common Reader - such as Samuel Johnson himself - could not miss an opportunity to use this very Common

is „Zwykły czytelnik”. Unlike „przeciętny czytelnik” („an average reader”) or „masowy czytelnik” („a mass reader”) this term suggests a certain ontological complexity which may not be reduced to simple demographic facts or statistics. Obviously, if developed further, the critique of the idea of common reader should focus on all of the above terms in their specific contexts. 
Reader as a means of distinguishing themselves from the less literate crowd and strengthening their own authority. The appreciation of the masses always comes at a price.

What's interesting is that even in Kermode's brilliant analysis there is still a presupposition of some "other" kind of Common Reader, the one written in small letters, the "common reader" or "ordinary reader", whose nature and identity does not need to be explained. This dualism, I believe, is inevitable whenever one speaks from within the Johnson-Woolf tradition; even a critical and profound mind like that of Kermode is not able to go beyond this very basic opposition.

Another good example of this attitude is Harold Bloom's repeated statement that he is, in fact, a common reader writing for the other common readers. Obviously, such a declaration from a critic so commonly associated with a type of rigid intellectualism critical of the mass culture in almost all of its aspects may be read as an eccentric gesture of sorts, a brave (or just silly) attempt to enrich and refresh one's own public image. However, it seems that there is more to it. Bloom is aware that Johnson's original "common reader" no longer exists, yet he says that this is exactly the "common reader" he's trying to reach (Bloom 1991, 1996). Naturally, as long as the "common reader" is dead, it is the responsibility of the critic to protect the "common reader's" heritage. But what is important is the contradiction itself - because at the same time Bloom refuses to believe in his own statement, to acknowledge the common reader's death for more than a brief moment; for example, in a book allegedly written entirely for the "Common Reader", he openly states that "the Common Reader still exists and possibly goes on welcoming suggestions of what might be read" (Bloom 1995). The goal, it seems, is once again to suspend the idea of common reader in an area of unverifiability and undefiniability, where (s)he is neither "real" and autonomous nor "imagined" and dependent on the critic; although in more recent interviews Bloom seems to have given up on nostalgia and he embraces the common reader in a more unambiguous way (Bloom 2011). Those who criticize Bloom, on the other hand, tend to simplify things in much the same way as Eagleton did when he reviewed Jameson's book; they argue whether Bloom really writes "for" the common reader, but fall short of defining in any way who the "common reader" actually is (see i.e. Daly 2000).

Thus if we want to better understand the genesis and political character of the contemporary "common reader", it seems necessary to look 
for another tradition, somewhere outside of the Woolf-Johnson paradigm, popular culture studies and mainstream Marxist criticism. This tradition should be, obviously, familiar with the problems and phenomenons usually associated with the idea of "common reader", but at the same time it should be able to distance itself from the very category of "common reader"; capable of using another set of terms, figures and theoretical concepts. This tradition, I think, may be found within the field of the so-called everyday life studies.

Although not necessarily a separate (sub)discipline within humanities, the everyday life studies may certainly be seen as an autonomous tradition at the meeting point of culture studies, literary studies and political philosophy. The everyday life studies have their own "reader" (Highmore 2011), and, at least to a certain point, their own canon. ${ }^{2}$ If one were to briefly describe the history of this tradition, one could start, for instance, with Trotsky's, Kollantai's and Gastev's critiques of culture, then move on to the revolutionary and avant-garde movements of the 60s (COBRA,

The everyday life studies may certainly be seen as an autonomous tradition at the meeting point of culture studies, literary studies and political philosophy. Letterist Movement, Situationist International, then elaborate a bit on two great French thinkers - Henri Lefebvre and Michel de Certeau, and end the whole story with the contemporary scholars focusing on the problems of the daily life - predominantly British (i.e. Ben Highmore, John Roberts, Joe Moran, Bryony Randall).

Although the everyday life studies may hardly be seen as another "turn" in humanities, they certainly introduce an appealing attitude, a certain approach towards criticism of all things "common", "ordinary" and "daily". Through a critical analysis of the central term "everyday life" they manage to replace many intuitive terms with their more operational, more specific substitutes. The Situationists, for example, offered a reinterpretation of the idea of "culture" as "the reflection and prefiguration at any given historical moment, of the possible organization of daily life" (SI 2006a, 52) - and in turn they have tied the very notion of "daily life" to the problems of needs and desires. Michel de Certeau, on the other hand, has managed to redescribe the everyday life using the categories of "practices", "strategies" and "tactics". And more recently Ben Highmore has published a very interesting work about the idea of "indoors" and its history in XX-century Britain (Highmore 2014).

Now, it is quite clear that the "common reader" or the "ordinary reader" may be redescribed as an "everyday reader". It doesn't matter whether we assume Samuel Johnson's original perspective ("common

2 This is one of the conclusions of Liesl Olson's essay about the rising popularity of everyday life studies (Olson 2011). 
reader" as the reading bourgeois) or the more intuitive point of view ("common reader" as a member of the reading masses) - the "common reader" is the one who has enough time to read, and who may reconcile reading with his or her everyday activities. In other words, the "common reader" may be redefined as a person who's capable of making the activity of reading an integral part of his or her everyday life.

This is obviously not to say that "common reader" and the "everyday reader" mean the same; quite the contrary. This sort of redefinition does not happen spontaneously, nor is it instant or automatic; it is, in fact a process or a movement which we can grasp and analyse. In other words, this approach provides an opportunity to point out all the differences between the ordinary and the image of ordinary, between the everyday life and the idea of everyday life presented to us by the Spectacle. In fact, this is exactly what the studies of everyday life allow us to do: filter out all the assumptions and presuppositions which are normally hidden behind the seemingly self-explanatory notion of the "ordinary" - smuggled, if you will, like a small box of contraband on a ship full of perfectly harmless cargo.

Obviously, a coherent critique of the notion of "common reader" from the perspective of everyday life is not a task for a single academic, but for a team of researchers, writers and readers alike; such critique may not be limited to a single academical paper, but must result in a multitude of voices and a broader discussion. Thus, what I want to propose on the next few pages is just a preliminary discourse - an attempt to establish a certain perspective, perhaps; or just an example of how such a critique may be done. What I would like to do is to focus on the problem of the common reader's needs and desires. And although Michel de Certeau or Henri Lefebvre may seem like a better starting point for anything preliminary, I believe that the thinker who understood the relationship between the everyday and desire better than anyone else was Guy Debord.

\section{The Polish Common Reader}

But before I introduce Debord himself, I would like to offer a more solid background for my critique - preferably, by introducing some Polish context. Let me start with a very short personal reminiscence. About two years ago I had an opportunity to participate in a semi-scholarly discussion during a poetry festival in Warsaw. Although originally intended as a conversation about literary criticism as a form of art, 
our discussion swiftly drifted away towards the allegedly "critical" state of literary criticism in Poland. But this time, instead of the usual five minutes of self-denunciation and general cloth-tearing on behalf of the critics, a lot of criticism was directed against the publishing companies: namely, the publishers of papers, journals and magazines, who no longer take any responsibility for shaping and educating their own readers, for working with their supposed audience. One of the observations I have kept in mind since that discussion is that those few Polish cultural magazines that may be considered relatively "mainstream" and high-circulating are defined not by a specific purpose or a mission - their will to do something within the field of culture - but by their target, defined in a purely demographical way. Take, for example, „Książki. Magazyn do czytania" - technically, a literary supplement to the most popular Polish daily paper („Gazeta Wyborcz”), although published as a separate illustrated magazine. Its initial advertising campaign was based on a very simple message: „Książki” is a magazine for all those who read books but haven't found any other magazine about books they would be interested in. Certainly there are some niche literary journals, but none of them quite fit when the reader is a middle-class creative worker who has a lot on his/her head but wants to know all about the brand new biography of a controversial singer/activist/journalist from the 1970s. In other words, we are neither better nor worse than the others - we are simply "targeting" another demographic. One could perhaps call „Książki” a perfect example of a cultural project defined not by its purpose, but by its target - not by a certain set of goals and values, constantly shaped and re-shaped through the course of various discussions and political conflicts, but by a simple assumption that there is, somewhere out there, a certain type of person whom we simply need to reach (and then, obviously, convince him/her to purchase a specific commodity). This person is obviously the mythical Common Reader.

In Poland, common reader's popularity both in the scholarly and critical (or journalist) circles is barely documented or consciously reflected upon; the figure of the "ordinary reader" is invoked much more often during lectures, seminars and conferences than in scholarly essays. It certainly seems that (s)he prefers the spontaneity of a spoken exchange of opinions to the rigidity of the theoretical discourse. Stuck between the roles of enfant terrible and agent provocateur, at least at the Polish universities, the "common reader" usually acts as a sort of a helping hand or an invisible assistant to those scholars who want to either effortlessly link their own research to the problems of "real life" or even more effortlessly question the usefulness of someone else's research. 
But although the common reader rarely appears in the Polish academic discourse, it is once again impossible - due to the sheer volume of relative material - to offer a comprehensive comparison of its uses in cultural magazines and mainstream media. I would like to introduce just a few particularly interesting examples which, I believe, may be put together to form quite an interesting narrative about the common reader's nature.

First of all, it is clear that Kermode's understanding of the "common reader" - as a class-specific figure, distinct both from the "professional readers" and "uneducated masses" - differs quite significantly from the contemporary usage of the term in Poland. For example, in a panel discussion in 2010, Krzysztof Uniłowski explicitly stated that the common reader and the "educated" reader constitute two very distinct groups (or types) of readers (Łebkowska et al. 2010, 240). Some eight years before, in a column from 2002, he had already said that the critic's task is neither to "replace" nor to "represent" the common reader, which suggests that the primary distinction we're dealing with is between the "professionals" and the „non-professionals" (Uniłowski $2002^{3}$ ). Such a suggestion has been reiterated, in slightly different words, by Magdalena Gałkowska, a poet and a laureate of the prestigious Bierezin Award, for whom the common reader is simply anyone from outside the "literary circles" (Gałkowska 2014). Tadeusz Dąbrowski, a so-called "neoclassicist" poet and a literary celebrity, has stated the same thing, although in a more explicit and perhaps aggresive manner (Dąbrowski 2009). Stanisław Wójtowicz, one of the few self-proclaimed "libertarians" among Polish literary scholars and critics, in his review of a Stephen Greenblatt's book has basically divided the reading population into two main groups: "ideal" (or "professional") readers and "common" readers, with the third group consisting mainly of Greenblatt and Wójtowicz himself (Wójtowicz 2007). Yet another example of such an approach is a short essay written by Jerzy Jarniewicz and Maciej Świerkocki, editors of a book series entitled Twarze kontrkultury ("The Faces of Counterculture"). When describing the audience they would like to reach with the series, they divide the potential readers into four main groups: "artists", "students and professors", "subculturists" and "common readers" (Jarniewicz 2013). Piotr Śliwiński, arguably

3 It is worth noting that this short piece has been written as a criticism of an idealised image of the "common reader".

4 Wójtowicz has reiterated this simplified vision in one of his more recent papers; see Wójtowicz 2011. 
the most influential critic of contemporary Polish poetry, once stated that the "good" literature's distinctive feature is its ability to "free a common reader within a philologist", suggesting that this is one of the basic oppositions within the literary field (Śliwiński 19985). Jerzy Sosnowski, a novelist and radio personality, claims that due to a massive number of books being published today, both the booksellers and - "especially" the common readers need to trust the literary critics (Sosnowski 2011); here the third element is the person who represents the market itself (the bookseller), but still, the basic tension is the one between the common reader and the critic.

It seems particularly interesting that in none of the cases described above the "common reader" had any sort of an "additional" identity (man/woman, gay/straight, poor/rich, urban/rural, etc.).

In a piece from 2005, Krzysztof Uniłowski suggested that the "common reader", at least "from time to time", doesn't really mind reading a "highly imperfect" (literally: "half-brewed") book (Uniłowski 2005). This idea that the common reader's way of reading is (or at least might be) somehow simplified aesthatically or politically is apparently shared by Jerzy Sosnowski, who suggests that the basic "way" of reading practiced by the common reader is to "unceremoniously" compare one's own "experience of culture" to what the text says (literally: "to make them collide") (Sosnowski 2012). Another media personality, Rafat Bryndal - the editor-in-chief of the „Chimera” magazine - has claimed that the best way to reach the "common reader" is to "mix" some more complicated messages with the "lighter" content (the "mixing" itself, Bryndal claims, seems to help people broaden their horizons) (Bryndal 2012). In all of these cases, it is assumed that the very idea of "common reader" is self-explanatory; but although no one seems to ask about the common reader's needs or desires, the critics have a pretty clear image of how the common reader works or acts. This implies that the common reader's needs and desires are non-dynamic; they do not change in time; they may not be transformed by an aesthetic experience (reading a book, talking to an author, reading a review, etc.).

I believe it is possible to point out some common assumptions shared, implicitly or explicitly, by all of the critics and authors quoted above. Nonetheless, I feel I need to stress the fact that there are some huge differences between them; and although, for example, Krzysztof Uniłowski may sometimes use this simplified notion of the "common reader",

5 This particular part of Śliwiński's essay has been cut from the version published in a well-known anthology Kartografowie dziwnych podróży (Śliwiński 2004). 
his brilliant critical insight has allowed him to make some very interesting observations the class background of contemporary Polish literature and its readers. ${ }^{6}$ This is not the case with authors such as StanisławWójtowicz and Rafał Bryndal, who may be seen as the good cop/bad cop duo of the neoliberal agenda; Wójtowicz being the libertarian hard-liner with the academic background and Bryndal posing as the overenthusiastic, always-smiling activist in charge of a commercially successful magazine.

Either way, at this point I would like to summarize some common assumptions (and offer some conclusions as well):

- the whole idea of common reader is embraced as self-explanatory it is assumed that everyone may get in touch with the common reader through some rudimentary thought experiment;

- despite being presented as an autonomous - and, indeed, somehow primordial - force within the literary field, the common reader is always seen in relation to the critic;

- common reader is defined not by his/her "needs" and "desires", but by the way in which (s)he "acts" or "responds" to certain phenomenons;

- $\quad$ this implies that his/her needs and desires do not change (significantly) in contact with a particular book or cultural phenomenon;

- the common reader is never described as possesing any sort of a "particular" identity or social background (class, race, gender, etc.); (s)he is never simultaneously a common reader and a woman, a common reader and a Jew, a common reader and a worker, etc.

It should be probably stressed once more that if the above observations seem somehow scattered - chaotic, even - it is because there is virtually no deliberate critique of the idea of the "common reader" in Poland. There are no attempts to define this term, let alone to give it some new, less intuitive meaning.

In this context, it is worth noting that one of the most influential and insightful books of literary criticism published in Poland in the last twenty years - namely, Przemysław Czapliński's The Return of the Centre (Czapliński 2007) - uses a quote from Harold Bloom as an opening for one of its chapters: "Krytyk jest zwykłym czytelnikiem u szczytu sił"

6 See i.e. Uniłowski 2008. Another essay in the same book, $Z$ popem na ty, offers one of the best analysis of how the line dividing the "common reader" and the "professional reader" is being blurred in the contemporary academia. 
(back-translation to English: "The critic is a common reader raised to the highest power"). ${ }^{7}$ The term "common reader", however, does not appear on the following pages, with Czapliński focusing instead on the changing role of literary criticism in post-socialist Poland. Nonetheless, in the conclusion of the chapter, Czapliński reflects on the relationship between the contemporary literary criticism and the general collective subject ("us") - which, as the context suggests, may be seen as the community of the "common readers". According to Czapliński the task of the critic is to simultaneously embrace and subvert the expectations of the common reader (Czapliński 2007, 131-132). In this sense, the chapter may be seen as a rudimentary starting point for a critique of the common reader; however, following the steps of Bloom himself, Czapliński refrains from defining in any way who the "common reader" - the collective "we" - actually is. Thus, although Czapliński provides a set of useful hints on how to undertake a credible critique of the common reader, he does not undertake such a critique himself.

\section{What Does the Common Reader Want?}

Let us now introduce Guy Debord's point of view: ${ }^{8}$

The really experimental direction of situationist activity consists in setting up, on the basis of more or less clearly recognied desires, a temporary field of activity favorable to these desires. This alone can lead to the further clarification of these simple basic desires, and to the confused emergence of new desires whose material roots will be precisely the new reality engendered by situationist constructions.

7 Czapliński 2007, 88. The quote comes from the Polish translation of Bloom's book (Bloom 2002). It is worth noting that Czapliński wouldn't be able to use that quote, were he to refer to the original version; the whole sentence reads: "Is it useful to be told that poets are not common readers, and particularly are not critics, in the true sense of critics, common readers raised to the highest power?". Bloom's goal here is not to define the role of the critic, but to reflect on the peculiar status of a poet; and considering his characteristically broad understanding of "poetry" and "poets" one could wonder whether the kind of criticism Czapliński writes about doesn't go into the territory of the latter.

8 Obviously, it is not possible to summarize here the Situationist theory of needs and desires. For an introduction as well as a deepened analysis see i.e. Werk 2011, 2013, Jappe 1999, Roberts 2006. 
We must thus envisage a sort of situationist-oriented psychoanalysis in which, in contrast to the goals pursued by the various currents stemming from Freudianism, each of the participants in this adventure would discover desires for specific ambiences in order to fulfill them (SI 2006b, 49-50).

This is Debord at his least radical. Contrary to his habit of beginning every theory and action with some concrete knowledge, an almost-scientific statement, this time he wants to start with "more or less clearly recognized desires" - a hint perhaps, or just a feeling; an impulse or an irrational action. The situationist model of a "living" participant in arts or culture, the "liver" of a situation, is therefore based on the assumption that desires are simultaneously created, discovered and fulfilled within the situation as a "true" and meaningful politico-cultural experience. In fact, "experience" is not the best word to describe this concept Debord has time and again underlined the fact that situation is a very precise spatio-temporal construct, more of a visible and definable "event" than an abstract "experience". The goal of a "director" of a particular situation - and its cooperating "agents" - is to create frames within which the desire may emerge and fulfill itself. This vision stands in strong opposition to the idea of "common reader", whose status as a "primitive" reader implies that the bases of his/her desires were formed before any sort of cultural activity or critical thought. And yet, as we can clearly see, Debord's vision is not a utopian one - in his basic description of what the situations do to their participants (basic desires are clarified, new, more complex desires emerge) Debord is actually disturbingly close to our own intuitions and beliefs about how culture and art should function in a "good", "healthy" or "happy" society, on an "everyday" basis. ${ }^{10}$

But at the same time what the French philosopher says is that there is no place for articulating, shaping or discovering desire within the spectacularised, market-driven "society". Of course, there is - sometimes very deeply rooted - an illusion of desire, a strong conviction that, for instance, underneath the linguistic apparatus of an advertisement there is a "real" need to be fulfilled. The problem is that for the spectacle to be effective it has to be autonomous as well - thus, it constantly

9 This is the term used in Ken Knabb's translation.

10 This is precisely where approaching Debord from the point of view of the "everyday life studies" allows us to go beyond some common assumptions about the Situationist theories. In order to apply the Situationist critique to various problems of contemporary culture, it seems necessary to stress the fact that the utopian moment of Situationist thought is always surprisingly close to the most intuitive, down-to-earth ideas about what the art or culture should be about. 
gravitates towards the very antithesis of life and society, effectively repressing or even eradicating every "real" desire. Indeed, the spectacle is capable of capturing and processing the subject's desire, but the whole process is barely noticable. One could argue that the idea of "common reader" is located precisely where the subject's desire is being captured by the spectacle. Here the critic's intuition is still vivid ("there must be a common reader somewhere out there"), but there is no longer any "below" or "beyond" where the desire could be preserved and redi-

Thus, although

the situationists' vision of culture was radically democratic, egalitarian and so on, the only way to fulfill it - according to situationists themselves - was through constructing more and more complex forms of art, as opposed to any sort of an "artful simplification". It is always about moving upwards, towards the "higher" forms of culture - which, of course, goes along well with Debord's fondness for military analogies and his criticism of the "mystics of non-organization". scovered - what remains is only the superficial negation of the spectacle (the common reader as non-intellectual, non-professional, etc.).

This much - the importance of "situations", the autonomy of the spectacle, the need to regain or recreate desire - is pretty clear as far as Debord's vision of the "new participant in culture" is concerned. But there is one more key element which many of Debord's readers tend to omit - the question of the "supreme" cultural forms. The only way of surpassing the spectacle, of intervening against it, of creating a meaningful situation and filtering out the false desires (or needs posing as desires) is by achieving new forms of art and culture which would be more complex, "supreme" and "higher" than the ones we already know. It is only through complexity that the status quo may be destabilised; and the more complex the situations get, the larger part of reality they encompass, thus allowing for a progressively holistic perspective. And as Debord and his followers teach, a critique of the Spectacle may be efficient and meaningful only if it's a critique of the Spectacle as a whole (see i.e. Wark 2013, 3-4).

Thus, although the situationists' vision of culture was radically democratic, egalitarian and so on, the only way to fulfill it - according to situationists themselves - was through constructing more and more complex forms of art, as opposed to any sort of an "artful simplification". It is always about moving upwards, towards the "higher" forms of culture - which, of course, goes along well with Debord's fondness for military analogies and his criticism of the "mystics of non-organization"(Riesel 2006 ${ }^{11}$ ). A lot has been written about this curious aspect of the Situationist thought - it would be an oversimplification to call it an opposition of "elitarism" and "egalitarism", but there is certainly an unresolved tension between organisation/tactics/appreciation of form on the one hand, and play/spontaneity/creative chaos on the other. This tension may be seen in some of the key Situationist concepts an obvious example being détournement, but also dérive (and the idea

11 This particular phrase was used by Riesel, but his essay - published in the last issue of SI -can be read as a manifesto of the whole group. 
of psychogeography in general), where the spontaneity of flâneur's walk is mixed with the military-like tactical approach to urban space. But this is probably beside the point. In the context of the "common reader" it is first and foremost important to notice that only through more supreme and complex forms of art the reader may actually invent any desire worth fulfilling. If Debord was to comment on the vision of Samuel Johnson and Virginia Woolf, or its contemporary reiteration, he could have said that it's not before the common reader surpasses the boundaries of the Common Reader that he may be considered a "good" reader at all. Indeed, if the Common Reader serves as a means of distinguishing oneself from the masses and preserves the illusion of a "real" ("primitive", "untainted") desire being somewhere out there, then (s)he is the perfect ally of the Spectacle.

Introducing the category of Spectacle may help us explain the peculiar status of the idea of "common reader". As I've been trying to prove, when used in an affirmative way, the notion of "common reader" almost always implies a certain simplification on the part of the critic. It is simply not true, there is no separate population of "common readers" without class or gender, who behave in this sort of a simplified, zombie-like way. But at the same time the idea of "common reader" is being reproduced every day not only by critics and writers, but also by mainstream journalists, media personalities, cultural institutions and online bookstores. We are constantly being told that the common reader is "out there" and that his/her actions influence all of us, to a point where some of the professional critics may start believing they are actually able to become the "common readers" themselves, or at least to somehow emulate the common reader's behaviour (such is the premise of some of the recent books by a well-known Polish literary scholar, Michał Paweł Markowski - see i.e. Markowski 2009, 2010). If what Debord said about the nature of the Spectacle is true - specifically that the Spectacle is not about images, but about a social relationship mediated by those images - than we may consider the "common reader" a very handy image, used by the Spectacle to transform the relationship between the critics, readers, publishers, etc. Here one encounters one of the basic difficulties in criticising the idea of the common reader: there is virtually no difference between the concept/idea/figure of the "common reader" (as "it") and the image of the common reader as an existing person (as "she/he"). To conclude this part with Debord's own words, one could refer to the famous statement from Thesis 9 of The Society of the Spectacle (one of Debord's skillful détournements of Hegel): In the world that is really inverted, the true is a moment of the false. 
As some sort of a general conclusion of this preliminary discourse, I would like to offer a few intuitions about the direction in which the critique of contemporary "common reader" could be developed.

As we have seen, the common reader has no inherent features like class, gender, race or sexual orientation. (S)he is usually "uneducated", but only in the meaning of "without a $\mathrm{PhD}$ or a university-level preparation". Common reader may be thus considered an epitome of the middle-class aversion to any great narratives, radical statements and political allegiances. (S)he does not belong to any particular class, because "common reading" is available - as a lifestyle choice - to people on virtually any level the of socio-economic hierarchy. Of course, the common reader is defined partly by his/her lack of access to some of the means of producing interpretations; but those specific means that are kept away from him/her consist solely of the "professional", theoretical and scholarly tools. In other words, as long as you're not a professor, a critic or a cultural activist, you will make a great ordinary reader - never mind how often you are able to go to the movies, buy a book or visit a museum.

Of course, things are a bit different when it comes to the common reader's cultural identity. Obviously, at some point his/her identity somehow has to be defined and decided; (s)he can't be male and female at the same time and (s)he would become too abstract if (s)he were to abstain from choosing any specific gender. But his/her identity seems nothing more than a contingent mask or a prism filtering out some of the potential features and leaving others intact, dividing between various stereotypical images. Whereas his/her "ordinary" or "common" nature is a primary and constant feature, the common reader's gender, sexual orientation or ethnic identity is secondary and occasional. For instance, the "female ordinary reader" is exactly this - a female (sub)type of an ordinary reader and not a woman reading in an ordinary way.

Every appearance of the common reader brings to mind an image of a so-called decision tree or an interactive novel. For example, if the common reader is a woman from a big city, than she's going to like a biography of some nineteenth-century emancipated lesbian writer; if the common reader's family comes from Kresy Wschodnie - Polish Eastern Borderlands - (s)he's going to love a sentimental family saga about a world long past, etc. Of course, quite often this way of thinking will prove completely wrong, but $40 \%$ is probably still good enough from the market perspective. It's almost like buying a last minute gift for a cousin you don't really care about. 
If at some point in the history of literature the "common reader" has become less of a socio-economical concept and more of a cultural identity, then nowadays we can see yet another shift - from the identity as such towards the "commonality" or "ordinariness" as a general characteristic, stable and independent of all the particular features. And what really defines the common reader's basic condition is no longer his/her need, urge or desire, but his/her ability to like and prefer. Where in the situationists' vision there was a common ground of everyday life, here one finds a network of individualised choices. Where there was a complex play of different desires, wants, needs, urges, etc., there is now a stable and predictable network of different "preferences". The preferences, in turn, may be seen as pre-existing desires, the sort of non-dynamic, "always-there" desires that are characteristic of the "common reader". They are always defined on the basis of previous choices and only in relationship to two or more desirable objects - I'm talking here about the "buyer's preferences" deduced by an algorithm used by your average online bookstore. Even if the preferences change, you can never witness the moment of change, for they're always already there. And, perhaps most importantly, "expressing" one's preferences means simply reporting their current state - it has nothing to do with "creating" or "reshaping" them. In this, preferences dramatically differ from desire as such. They always seem to accommodate existing tastes, because they are nothing more then information about those tastes.

By liking something the common reader gains an illusion of identity, but more importantly, (s)he places himself/herself on the market sending out a signal that can be read and processed accordingly by the market-oriented cultural institutions. By preferring something to something (s) he is able to solve, or rather omit, various conflicts; instead of arguing if one work of art is better or worse than the other, (s)he can take a side-step justified by his/her untouchable right to prefer this or that. In other words, liking makes the common reader visible for the market, and preferring allows him/her to preserve his/her apolitical, neutralised and conflictless status.

There are at least three important consequences of the above observation. First of all, from the point of view of the traditional cultural institutions, working with the (potential) reader becomes pointless. Of course, it's important to get to know him/her, to reveal his/her tastes and describe his/her experiences, but that's about it.

Secondly, all the experimental forms of art, especially the ones intervening in the public space, become pointless as well. There is no need and indeed no legitimate way - to help the audience discover and reshape
By preferring something to something (s)he is able to solve, or rather omit, various conflicts; instead of arguing if one work of art is better or worse than the other, (s)he can take a side-step justified by his/her untouchable right to prefer this or that. In other words, liking makes the common reader visible for the market, and preferring allows him/her to preserve his/her apolitical, neutralised and conflictless status. 
their own desires. Discovering the desires of a common reader - in their caricature form of likes and dislikes - is a completely pre-textual activity, meaning that it happens entirely before the text, before the act of reading. First one has to know what the common reader likes, so then he can offer a specific selection of literary works. Experimental art, as a form of "probing" the audience's desires, has no place in the equation.

Thirdly, instead of creating more and more complex forms of art - as was the case with the idea of "situations" - one should now focus on mixing together various simple messages, creating as many different combinations as possible (but at the same time preserving the general simplicity and straightforwardness of the message). On the one hand, this is the very principle of the spectacle: mixing true impulses with false desires to the point of indistinguishability. On the other hand, this is the only way of establishing a dialogue with the common reader as described above: if you like this (and I know you do, because I have seen your PayPal history), then you may want to take a look at this. And if you don't like this, you should seriously consider that. I gather information about all your previous choices and come up with a suggestion, to which you respond simply "yes" or "no". This chain of vulgar recommendations, based on a linguistic automatism and a simple algorithm, lies at the very core of both Google and Amazon. Coincidentally, this is also what Rafat Bryndal describes as his vision of a perfect literary magazine (Bryndal 2012).

But, obviously, it is never as bad as it seems. And looking back to the times of Situationist International may provide some interesting solutions for today's problems.

But before that I would like to refer to a recent poem by one of the best Polish poets of the young generation, that is Szczepan Kopyt. Uderzenie meaning "the beat" or "the hit" - is a poem from his last book; it is a long, "spokenword-ish" poem heavily influenced by Saul Williams, jazz poets and Bruno Jasieński. Near the end of this poem there is a simple, although meaningful commentary; sort of a sidenote, if you will, parallel to the central flow of images.

just a short comment on the side this poem is not pointed at the reader the reader says its words inside his head and knows to whom it's addressed the audience doesn't take it personally but you who have your conscience /smeared with clotted labour time take a look at the cities and the streets

(Kopyt 2013) 
Instead of "pointed at" one could use the phrase "targeted at". Something very interesting happens here: firstly, Kopyt speaks openly about the "conscience", which he doesn't do often - in fact, it seems like a risky step in the context of contemporary Polish poetry, which tends to strongly privilege irony in all its instances. We can almost see Kopyt putting on the mask of a moralist. Secondly, he refuses to "target" his poem at a potential reader - this time the poem is more of a weapon, a gun pointed at those who "have their conscience smeared". Thirdly, the whole "comment on the side" thing seems a tad arrogant, almost annoyingly arrogant - there's some intrinsic discomfort within those verses, a feeling that the poet stepped over the line - and even worse, that he may be right.

I think this is the same kind of arrogance that marked Debord at his finest. When he radically - and, yes, sometimes hegemonically claimed that the situationists knew how to answer human desires and needs, when he argued that every situation has to have a "director" and that structurelessness is a harmful myth - then he showed this kind of annoying arrogance.

Of course, in the world of "likes" and "dislikes" a poet who chooses to act like this seems to willingly take on the role of a scapegoat; but there's more to it. His actions allow for an important shift from the common reader as a static, unidentified and unclassified figure of "likes" and "preferences" back to the common ground of everyday life, to the discussion about what we need, want and desire. It's very poetical in the best meaning of the word. We don't have to give up on the democratic ideals, quite the contrary, but the potential for a dialogue is reinstated. The consequences, both political and cultural, may be quite far reaching. 


\section{Bibliography}

Altick, Richard. 1957. The English Common Reader: A Social History of the Mass Reading Public 1800-1900. Chicago: University of Chicago Press. Bloom, Harold. 1991. "The Art of Criticism." By Antonio Weiss. The Paris Review No. 118. http://www.theparisreview.org/interviews/2225/the-art-of-criticism-no-1-harold-bloom Bloom, Harold. 1995. The Western Canon: The Books and School of the Ages. London: Macmillan.

Bloom, Harold. 1996. "An Interview with Harold Bloom." By José Antonio Gurpegui. Revista Alicantina de Estudios Ingleses 9.

Bloom, Harold. 2011. "An Interview with Harold Bloom on Literary Criticism." http://fivebooks.com/interviews/harold-bloom-on-literary-criticism Bloom, Harold. 2002. Lęk przed wptywem: Teoria poezji. Trans. Agata Bielik-Robson i Marcin Szuster. Kraków: Universitas.

Bryndal, Rafał. 2012. "Legalna kultura to sposób myślenia." By Tomasz Kin. http://legalnakultura.pl/pl/czytelnia-kulturalna/rozmowy/news/498, legalna-kultura-to-sposob-myslenia

Czapliński, Przemysław. 2007. Powrót centrali: Literatura w nowej rzeczywistości. Kraków: Wydawnictwo Literackie.

Dąbrowski, Tadeusz. 2009. "Stała Enzensbergera." By Aleksandra Kozłowska. http://www.wysokieobcasy.pl/wysokie-obcasy/1,96856,7225405,Stala_ Enzensbergera.html

Daly, Macdonald. 2000. „Nipping Bloom in the Bud: A Critique of the Western Canon." Revista Brasil de Literatura [Literaturas de Lingua Inglesa] 3. http://lilipe.tripod.com/ingles/bloom3.htm\#fn0

Eagleton, Terry. 2009. „Jameson and Form.” New Left Review 59.

Fadiman, Anne. 2000. Ex Libris: Confessions of a Common Reader. New York: Farrar, Straus and Giroux.

Gałkowska, Magdalena. 2014. "Nagrody i koszmary." http://silesius.wroclaw. $\mathrm{pl} / \mathrm{p}=1153$

Highmore, Ben. 2011. The Everyday Life Reader. London: Routledge. Highmore, Ben. 2014. The Great Indoors: At Home in the Modern British House. London: Profile Books.

Jappe, Anselm. 1999. "The Situationist Critique in Historical Context." In Guy Debord. Trans. Donald Nicholson-Smith. Berkeley: University of California Press. Jarniewicz, Jerzy, and Maciej Świerkocki. 2013. "Twarze kontrkultury.” http://www.officyna.com.pl/seria-10

Kermode, Frank. 1983. “The Common Reader." Daedalus 1.

Kopyt, Szczepan. 2013. "Uderzenie.” In Kir. Poznań: WBPiCAK.

Łebkowska, Anna, Anna Pochłódka, Krzysztof Uniłowski and Krystyna 
Wilkoszewska. 2010. "Literatura a nowe media." Dekada Literacka 1-2. Markowski, Michał Paweł. 2009. Żcie na miarę literatury. Kraków: Homini 2009. Markowski, Michał Paweł. 2010. Stońce, możliwość, radość. Warszawa: Czarne 2010. Olson, Liesl. 2011. "Everyday Life Studies: A Review." Modernism/modernity 1. Riesel, René. 2006. "Preliminaries on Councils and Councilist Organization”. In Situationist International: Anthology. Trans. Ken Knabb. Berkeley: Bureau of Public Secrets.

Roberts, John. 2006. "The Situationist and the Philosophy of Praxis." In Philosophizing the Everyday: Revolutionary Praxis and the Fate of Cultural Theory. London: Pluto Press.

SI. 2006a. "Definitions." In Situationist International: Anthology. Trans. Ken Knabb. Berkeley: Bureau of Public Secrets.

SI. 2006b. "Preliminary Problems in Constructing a Situation." In Situationist International: Anthology. Trans. Ken Knabb. Berkeley: Bureau of Public Secrets. Sosnowski, Jerzy. 2011. "W obronie metafizyki." Więź 5-6.

Sosnowski, Jerzy. 2012. “O B. Prusie z Jerzym Sosnowskim.” By Krzysztof Lubczyński. http://pisarze.pl/publicystyka/2587-krzysztof-lubczynski-ob-prusie-z-jerzym-sosnowskim-.html

Śliwiński, Piotr. 1998. "Inna krytyka?” Znak 7. http://www.opoka.org.pl/ biblioteka/I/IL/inna_krytyka.html

Śliwiński, Piotr. 2004. "Inna krytyka.” In Wyka, Marta, Wyka, Marta and Krzysztof Biedrzycki. Kartografowie dziwnych podróży. Kraków: Universitas.

Uniłowski, Krzysztof. 2002. “Wojna Stasińskiej”http://www.fa-art.pl/ archiwum/wersja1/12027.php

Uniłowski, Krzysztof. 2005. “A nas przy tym wszystkim nie było”https:// www.fa-art.pl/artykul.php?id_artykulu=338\&szablon=autorzy_artyk_felieton Uniłowski, Krzysztof. 2008. “Mit powieści mieszczańskiej.” W Kup pan książę! Katowice: Wydawnictwo FA-art.

Wark, McKenzie. 2011. "Permanent play." In The Beach Beneath the Street. New York: Verso.

Wark, McKenzie. 2013. "Widening gyres." In The Spectacle of Disintegration. New York: Verso.

Woolf, Virginia. 2013. "The Common Reader." In The Common Reader: First Series. New York: Sullivan Press.

Wójtowicz, Stanisław. 2007. "Służąc dwóm panom." Podteksty 3.

Wójtowicz, Stanisław. 2011. "Kryzys legitymizacji literaturoznawstwa." Teksty Drugie 6. 
Paweł Kaczmarski (1991) - lives in Wrocław. Student at the Adam Mickiewicz University in Poznań, Poland. Literary critic. Laureate of the third edition of the "Diamond Grant" program. Editor-in-chief of "Przerzutnia" - an academic journal of literature and everyday life studies.

\section{Address:}

Paweł Kaczmarski

Instytut Filologii Polskiej UAM

ul. Fredry 10, 61-701 Poznań

Collegium Maius

e-mail: pawel.kaczmarski@przerzutnia.pl

\section{Citation:}

P. Kaczmarski, A few notes on the contemporary common reader, „Praktyka Teoretyczna” nr 1(11)/2014, http://www.praktykateoretyczna.pl/PT_nr11 _2014_Socjologia_literatury/04.Kaczmarski.pdf (dostęp dzieńmiesiącrok)

DOI: $10.14746 / p t .2014 .1 .4$

Paweł Kaczmarski (ur. 1991) - mieszka we Wrocławiu. Student Uniwersytetu im. Adama Mickiewicza w Poznaniu. Krytyk literacki. Laureat trzeciej edycji programu „Diamentowy Grant”. Redaktor naczelny „Przerzutni” - czasopisma naukowego poświęconego literaturze i badaniom nad codziennością.

Abstrakt: W moim artykule staram się naszkicować punkt wyjścia dla krytyki pojęcia „zwykły czytelnik” - w takim rozumieniu, jakie nadaje mu współczesna krytyka literacka. „Zwykły czytelnik” został stworzony jako osobny teoretyczny konstrukt przez Samuela Johnsona i spopularyzowany przez Virginię Woolf. Dzisiaj ta idea jest dalej popularyzowana i upraszczana - choć w dużej mierze nieświadomie - przez krytyków i dziennikarzy głównego nurtu jako sposób na usunięcie z debaty publicznej możliwości autentycznego politycznego konfliktu. "Zwykły czytelnik” jest postrzegany jako czytelnik bez klasy, tożsamości czy społecznego tła. Staram się pokazać, że w celu podjęcia wiarygodnej i systematycznej krytyki „Zwykłego czytelnika” należy wyjść poza paradygmat wyznaczony przez Johnsona i Woolf i odwołać się do tzw. studiów nad codziennością - inspirowanej sytuacjonistami tradycji na pograniczu badań kulturowych, teorii literatury i filozofii polityki.

Słowa kluczowe: zwykły czytelnik, sytuacjoniści, Spektakl, codzienność, krytyka literacka 